Vol. 4: 479-494.

\title{
Effects of plant species and harvesting system on grassland production in northern Finland
}

Oiva Nissinen

Agricultural Research Centre of Finland, Lapland Research Station, Tutkijantie 28, Apukka, FIN-96900 Saarenkylä, Finland

Heikki Hakkola

Agricultural Research Centre of Finland, North Ostrobothnia Research Station

\begin{abstract}
The dry matter yields and forage quality of seven grassland plant species and mixed stands which included three cutting regimes (pasture 4-5 cuts, silage 2-3 cuts, hay and aftermath) were studied at two locations in northern Finland, Ruukki $\left(64^{\circ} 40^{\prime} \mathrm{N}\right)$ and Rovaniemi $\left(66^{\circ} 35^{\prime} \mathrm{N}\right)$. Increased cutting frequency lowered the total dry matter yields of all plant species. Production of timothy (Phleum pratense $\mathrm{L}$.) and smooth brome grass (Bromus inermis $\mathrm{L}$.) swards was significantly reduced by taking four or five cuts instead of one or two cuts. Meadow fescue (Festuca pratensis Huds.) and meadow grass (Poa pratensis $\mathrm{L}$.) showed only a minor interaction with harvesting regimes and were less affected by the cutting frequency. The increased cutting frequency raised the crude protein content, this causing the highest protein yields despite the smaller dry matter yields. The inclusion of red clover in seed mixtures had a favourable effect on the crude protein content of grass swards.

Stands of sown plants decreased and the proportion of weeds in yields increased with time, reflecting the suitability of plant species to various cutting regimes. Meadow fescue and meadow grass with rapid regrowth had a positive effect on sward density and also caused less invasion of weeds when the cutting frequency was increased.
\end{abstract}

Key words: cutting frequency, dry matter, forage quality, botanical composition, Phleum pratense $L$., Festuca pratensis Huds., Poa pratensis L., Bromus inermis L., Trifolium pratense L.

\section{Introduction}

Agriculture in northern Finland relies heavily on livestock, and nearly $80 \%$ of the cultivated area is used for growing grass forage, i.e. hay, silage, and pasture. The plants best suited for cultivation under northern conditions are grasses with abundant vegetative growth, as they grow well in a cool climate and can benefit from the long day (Landström 1989). The production of grassland plants is, however, impaired and the number of harvests reduced by the shortness of the growing season (Pulli 1982). Moreover the most winterhardy northern varieties grow very rapidly in the middle of the summer, but very slowly in late summer. On the other hand, the number of cuts is determined by the time of the last cut. This has to be chosen to ensure that the gathering of food reserves and hardening can take place be- 


\section{AGRICULTURAL SCIENCE IN FINLAND}

\section{Nissinen, O. \& Hakkola, H.: Effects of cultivation technique on grassland production}

fore the onset of the long winter (Hakkola et al. 1987). As the time of harvest is linked to the development stage of the stands, some sort of aftermath crop is also harvested in northernmost Finland.

There is demand for good-quality grass forage for both summer and winter feeding. The most important factor influencing total yields is cutting frequency. Advanced mechanization in modern grassland management for silage-making has resulted in the use of intensive cutting systems. In northern Finland, however, this type of management has caused problems to grassland yields and the viability of some plant species.

In northern Finland, the straw formation of plants and the sharp increase in dry matter content in early summer cause rapid changes in forage quality. Fibrousness increases, and the crude protein content and digestibility decrease (Pulli 1980, Huokuna and Hakkola 1984). On the other hand, low temperatures reduce the fibrousness of the plants in the north. At the same morphological development stage, plants in the north have better digestibility than those in the south (Deinum et al. 1981). In the autumn, stands are leafier and changes occur more slowly.

Strong straw formation and slow regrowth are typical of timothy (Phleum pratense L.) and smooth brome grass (Bromus inermis L.).

Straw formation in meadow fescue (Festuca pratensis Huds.) and meadow grass (Poa pratensis L.) is less strong and regrowth is better. Due to its better regrowth ability, meadow fescue thrives better than timothy in pasture and silage swards (Järvi 1976, Grönneröd 1988). Meadow grass, too endures many harvests during the growing period better than timothy (Grönneröd 1972, Landström 1978). Meadow grass has also had a higher yielding regrowth than timothy (Mason and Lachance 1983). Smooth brome grass has been found to thrive even more poorly than timothy in pasture and silage swards (Grönneröd 1972, Järvi 1982), whereas in hay swards, it has given high yields. The total yield of a mixture of timothy and meadow fescue is often higher than that of pure stands of either plant species alone (Raininko 1968, Hakkola 1988, Jörgensen et al. 1994). Under variable growth and wintering conditions, a mixed sward also tends to be more reliable for cultivation than a pure stand (Nissinen and Hakkola 1989, Jörgensen et al. 1994).

Owing to its good resistance to frost and ice encasement, timothy is most winterhardy in the south and on the coast. The winterhardiness of meadow fescue, which withstands snow scald (Sclerotinia borealis) better than timothy, improves the farther north it is cultivated (Landström 1978, Nissinen and Salonen 1972, Årsvoll 1977). In second-year leys, a rapid increase in the proportion of meadow fescue at the expense of timothy has been reported in mixtures of timothy and meadow fescue (Raininko 1968, Hagsand and Landström 1984, Nissinen and Hakkola 1989, Jörgensen et al. 1994). The yield of meadow grass has not markedly decreased with an increase in age (Landström 1978, Hagsand and Landström 1984). According to Andersson (1988), meadow grass is best suited for longduration pasture swards, and the farther north the better. Moreover, the yield of smooth brome grass has improved with the increasing age of the sward, and thus it is suitable for long-duration hay swards (Järvi 1976). Since red clover (Trifolium pratense L.) is not very permanent, the yield of a mixed sward containing clover diminishes more rapidly than that of pure grass mixtures (Hagsand and Landström 1984, Huokuna et al. 1985).

The protein content of meadow fescue is higher than that of timothy at the same developmental stage and at the same harvesting time (Salo et al. 1975). As, however, the yield of meadow fescue is often higher than that of timothy harvested at the same time, the protein content of the yield may be lower in meadow fescue than in timothy. The crude protein content is higher in meadow grass than in timothy (Landström 1978, Hole 1985). Many studies have further shown that the protein content of smooth brome grass is higher than that of timothy at the same development stage, harvesting time and yield level (Olsen 1978, Järvi 1982). Red clover 
Vol. 4: 479-494.

increases the crude protein content of mixtures. According to the findings of Andersson (1986, 1989), the nitrogen compensating effect of red clover on protein content is greater than the effect on the dry matter yield.

In mixtures of plant species, meadow fescue has been found to increase the fibre content owing to its earliness and red clover to reduce it (Hagsand and Landström 1984, Olsen 1978, Åman and Lindgren 1983). The fibre content of meadow grass is higher than that of timothy. Also, smooth brome grass has been found to contain more fibre in an early harvest than timothy and meadow fescue, but by the hay stage the fibrousness of timothy may be higher (Järvi 1982, Åman and Lindgren 1983). According to Olsen (1978), meadow fescue is more digestible than timothy when harvested at the same time. Correspondingly, timothy has been found to have better digestibility than meadow grass up to the flowering stage (Mason and Lachance 1983). Like meadow fescue, red clover has also improved the digestibility of plant species mixtures (Frankow-Lindberg 1989).

In northern Finland, grass forage accounts for almost $60 \%$ of the feed units used per milk cow, and thus grassland production is of very great economic importance to cattle farms. The aim of this trial was to investigate the effect of the harvesting system and cutting frequency on the yield and quality of different grassland plants in

Table 1. Plant species, varieties, seed mixtures and seed rates used in the trial.

\begin{tabular}{llr}
\hline Plant & Variety & \multicolumn{1}{c}{$\begin{array}{l}\text { Seed rate } \\
\mathrm{kg} / \mathrm{ha}\end{array}$} \\
\hline Timothy & Iki & 20 \\
Meadow fescue & Boris & 25 \\
Meadow grass & Jo 0011 & 20 \\
Smooth brome grass & Kesto & 30 \\
Timothy/red clover & Iki/Bjursele & $15 / 5$ \\
Timothy/meadow fescue & Iki/Boris & $13 / 13$ \\
Timothy/meadow fescue/ & Iki/Boris/ & \\
red clover & Bjursele & $10 / 10 / 5$ \\
\hline
\end{tabular}

northern Finland. In the field experiments, the superiority and suitability of the most important grass species and mixtures of plant species in pasture, silage and hay swards were compared. The main topics of interest were dry matter yield, forage quality and the persistence of a sown plant species when different cutting frequencies were used in forage management under the conditions of a short growing season and low temperature sum.

\section{Material and methods}

The trial was carried out during 1987-1992 at the Agricultural Research Centre of Finland's North Ostrobothnia Research Station in Ruukki $\left(64^{\circ} 40^{\prime} \mathrm{N}\right)$ and Lapland Research Station in Rovaniemi ( $\left.66^{\circ} 35^{\prime} \mathrm{N}\right)$.

The field experiments were set up using a split-plot method, with three harvesting systems - pasture, silage and hay - as the main plots. Plant species and their mixtures were as the split plots. There were four replicates. The species, seeding and nitrogen rates used in the trial are shown in Tables 1 and 2.

In Ruukki, the soil used was medium fine sand, pH 6.0, Ca 903, K 51, P 15 and Mg 42 mg/ 1. In Rovaniemi, the soil was fine sandy till, $\mathrm{pH}$ 5.95, Ca 1254, K 118, P 13 and Mg 165 mg/l.

The ground-cover percentage of the plot was evaluated visually in autumn and spring to reveal winter damage. Before harvesting, the heights of stands were measured and the maturing phase was evaluated on a scale of $0-100 \%$ $(100=$ all heads or panicles visible $)$.

The swards were harvested by a forage plot harvester (Haldrup). The cuts at pasture stage were carried out when the stands were approximately $30 \mathrm{~cm}$ high. There were three to five cuts. For grass species, the first silage crop was harvested when $20 \%$ of heads or panicles had appeared. In Ruukki, mixtures containing clover were cut later, at the start of clover flowering. In Rovaniemi, all plant species and mixtures were 
Nissinen, O. \& Hakkola, H.: Effects of cultivation technique on grassland production

Table 2. Fertilization of trial plots during years of harvest in 1988-1992.

\begin{tabular}{|c|c|c|c|c|c|c|c|c|}
\hline \multirow{2}{*}{$\begin{array}{l}\text { Harvest } \\
\text { system }\end{array}$} & \multirow[t]{2}{*}{ Locality } & \multicolumn{4}{|c|}{ Nitrogen/yield } & \multicolumn{3}{|c|}{ Total } \\
\hline & & 1 & 2 & 3 & 4 & $\mathrm{~N}$ & $P$ & $\mathrm{~K}$ \\
\hline \multirow[t]{2}{*}{ Pasture } & Rovaniemi & 80 & 50 & 40 & 40 & 210 & 35 & 140 \\
\hline & Ruukki & 90 & 60 & 50 & & 200 & 33 & 133 \\
\hline \multirow[t]{2}{*}{ Silage } & Rovaniemi & 110 & 80 & & & 190 & 32 & 127 \\
\hline & Ruukki & 120 & 80 & 50 & & 250 & 42 & 167 \\
\hline \multirow[t]{2}{*}{ Hay } & Rovaniemi & 80 & 60 & & & 140 & 23 & 93 \\
\hline & Ruukki & 90 & 70 & & & 160 & 27 & 107 \\
\hline \multicolumn{9}{|c|}{ Mixed stands with red clover (all harvesting systems): } \\
\hline & Rovaniemi & 62 & & & & 62 & 60 & 108 \\
\hline & Ruukki & 40 & & & & 40 & 60 & 108 \\
\hline
\end{tabular}

usually harvested at the same time. Each year, two or three silage crops were harvested. Hay swards were harvested when the stands were in full head or panicle and red clover was in full flower. In Ruukki, the last cut was carried out right at the beginning of September, and in Rovaniemi around 20th August.

Botanical composition was determined from combined samples of about $500-1000 \mathrm{~g}$ from all replicates of the treatments. In some cases, the botanical composition of the pure stands of timothy, meadow fescue, meadow grass and smooth brome grass was assessed visually as the coverage of sown and unsown species. One representative crop sample from different replicates of each treatment was taken and analysed for dry matter, crude protein and fibre. Dry matter was determined by drying two parallel $200 \mathrm{~g}$ samples of the chopped plant, first for two hours at $100^{\circ} \mathrm{C}$ and then for 14 hours at $60^{\circ} \mathrm{C}$. For total nitrogen, the plant samples were analysed with the Kjeldatherm system (Gerhardt, Germany) and for fibre content with the Fibertec system (Tecator, Sweden). The digestibility of the organic matter was tested in vitro by the cellulaseenzyme method of Friedel (1990).

The effects of the harvesting systems and species and their interactions were determined by analyses of variance. For dry matter and crude protein yields the analyses of variance were carried out by the SAS program. The significance of the differences was tested using Tukey's test (LSD P $<5 \%$ ).

Due to the very different climatic conditions at the two research stations, experimental data were examined separately. Analyses of variance were made only for dry matter and protein yields. The crude protein yields of the replicates of the treatments were calculated by mean crude protein content of dry matter. Because of the lack of replicates, statistically reliable analyses could not be made for the botanical composition and qualitative values of grass forage.

At both trial sites the weather was warmer and rainier than the average during the trial period. In Ruukki, the growing period (daily mean temperature above $+5^{\circ} \mathrm{C}$ ) averaged 160 days, the effective temperature sum (degree-days, base $\left.+5^{\circ} \mathrm{C}\right) 1102^{\circ} \mathrm{C}$, and the precipitation in May-September $314 \mathrm{~mm}$. In Rovaniemi, the growing period was 132 days, the effective temperature sum $922^{\circ} \mathrm{C}$ and the precipitation $295 \mathrm{~mm}$. The average number of days with snow cover in Ruukki was 147, and in Rovaniemi 181. In all winters, the soil froze before the permanent snow cover formed. 


\section{AGRICULTURAL SCIENCE IN FINLAND}

Vol. 4: 479-494.

\section{Results and discussion}

\section{Sward overwintering}

The effect of harvesting method on the amount of winter damage was relatively slight (Tables 3 and 4). In Ruukki, most winter damage occurred in fourth- and fifth-year swards, and the main causes of damage were frost and ice scorch. In Rovaniemi, an increase in damage due to lowtemperature fungi was seen from the second crop year. At both trial sites there was more damage, on average, in swards harvested at the silage stage than in pasture or hay swards. In Ruukki, timothy suffered the least winter damage and meadow fescue the most. In Rovaniemi meadow fescue overwintered as well as timothy. Smooth brome grass had the highest annual variation in winter damage. At both trial sites, there was less winter damage in mixed swards than in pure stands.

According to this trial, timothy thrives considerably better than meadow fescue in Ruukki, which is situated on the coast, where the snow cover is shallow. Meadow fescue was most severely damaged by frost and ice scorch in old swards. Timothy has better resistance to ice encasement and frost than meadow fescue (Gudleifsson 1986). The winter climate in Rovanie$\mathrm{mi}$ is stable and the snow cover continuous throughout the long winter. As a result, attacks by snow moulds are a frequent problem. Meadow fescue is more resistant to snow scald (Sclerotinia borealis) than timothy (Nissinen and Salonen 1972, Årsvoll 1977). This explains the good overwintering of meadow fescue in Rovaniemi.

In this trial, the poorer overwintering of silage swards than of pasture swards may have been due to the timing of the last cut rather than to the harvesting system. For many years, the last cut was carried out earlier in silage swards than in pasture swards, and the aftermath left for overwintering had time to become more lush before the onset of winter. This increased the incidence of pink snow mould (Fusarium nivale) and of speckled snow mould (Typhula sp.) in the swards.

\section{Dry matter yields}

According to the statistical examination of dry matter yields, the differences between harvesting systems and plant species, and the interaction of these variables, were significant at both trial sites (Tables 5 and 6).

Increasing the number of cuts reduced the total yield of plant species and mixtures of plant species. The combined yield of dry hay and aftermath was the highest, and the yield of swards cut at the pasture stage was the lowest. The only exceptions to this were meadow fescue in Ruuk$\mathrm{ki}$, and meadow grass and smooth brome grass in Rovaniemi, which gave the highest yields of dry matter harvested at the silage stage. The effect of harvesting system on dry matter yields was greater in Rovaniemi than in Ruukki. At both trial sites, production dropped sharply in fourthand fifth-year swards.

In Ruukki, the plant with the highest average yield was smooth brome grass and in Rovaniemi, meadow fescue. Timothy yields were considerably higher in Ruukki than in Rovaniemi. Meadow fescue, in contrast, thrived more poorly than timothy in Ruukki, but in Rovaniemi gave higher yields than timothy. The highest yielding plant species mixture was timothy and meadow fescue and the lowest timothy and red clover.

The total yields of pasture swards in Ruukki were 5500 to $7680 \mathrm{~kg} / \mathrm{ha}$ in the first- to thirdyear swards, and 2180 to $4200 \mathrm{~kg} / \mathrm{ha}$ in the fourth- to fifth-year swards. The yield variations between plant species in Rovaniemi were 3340 to $6310 \mathrm{~kg} / \mathrm{ha}$ and 1570 to $4900 \mathrm{~kg} / \mathrm{ha}$, respectively (Table 6). The highest yielding plants were meadow fescue and meadow grass and the mixture of timothy and meadow fescue. The lowest total yield with four cuts was obtained from smooth brome grass. A comparison of swards of different ages shows that yields of dry matter dropped most rapidly in timothy and in smooth brome grass (Figs. 1 and 2). 


\section{AGRICULTURAL SCIENCE IN FINLAND}

Nissinen, O. \& Hakkola, H.: Effects of cultivation technique on grassland production

Table 3. Average winter damage and the proportion (\%) of sown plant species in first harvest of first- to fifth-year swards in Ruukki in 1988-1992.

\begin{tabular}{|c|c|c|c|c|c|c|}
\hline \multirow{2}{*}{$\begin{array}{l}\text { Plant species and } \\
\text { harvesting system }\end{array}$} & \multirow{2}{*}{$\begin{array}{c}\text { Winter } \\
\text { damage } \\
\%\end{array}$} & \multicolumn{4}{|c|}{$\begin{array}{l}\text { Percent sown plants } \\
\text { Year of ley }\end{array}$} & \multirow[b]{2}{*}{5} \\
\hline & & 1 & 2 & 3 & 4 & \\
\hline \multicolumn{7}{|l|}{ Timothy } \\
\hline Pasture & 3 & 100 & 100 & 100 & 40 & 61 \\
\hline Silage & 7 & 100 & 100 & 100 & 100 & 49 \\
\hline Hay & 2 & 100 & 100 & 100 & 47 & 31 \\
\hline \multicolumn{7}{|l|}{ Meadow fescue } \\
\hline Pasture & 20 & 100 & 100 & 100 & 100 & 39 \\
\hline Silage & 22 & 100 & 100 & 100 & 47 & 21 \\
\hline Hay & 11 & 100 & 100 & 100 & 24 & 13 \\
\hline \multicolumn{7}{|l|}{ Meadow grass } \\
\hline Pasture & 19 & 73 & 100 & 100 & 100 & 60 \\
\hline Silage & 21 & 77 & 100 & 100 & 100 & 50 \\
\hline Hay & 9 & 100 & 100 & 100 & 73 & 53 \\
\hline \multicolumn{7}{|l|}{ Smooth brome grass } \\
\hline Pasture & 21 & 100 & 100 & 39 & 85 & 15 \\
\hline Silage & 12 & 100 & 100 & 100 & 100 & 26 \\
\hline Hay & 12 & 100 & 100 & 100 & 87 & 93 \\
\hline \multicolumn{7}{|l|}{ Timothy/red clover } \\
\hline Pasture & 5 & & & & & \\
\hline Timothy & & 92 & 82 & 81 & 47 & 56 \\
\hline Red clover & & 5 & 18 & 7 & 3 & 12 \\
\hline Silage & 6 & & & & & \\
\hline Timothy & & 90 & 52 & 57 & 47 & 44 \\
\hline Red clover & & 7 & 45 & 30 & 22 & 28 \\
\hline Hay & 5 & & & & & \\
\hline Timothy & & 87 & 77 & 62 & 55 & 56 \\
\hline Red clover & & 13 & 20 & 23 & 2 & 10 \\
\hline \multicolumn{7}{|l|}{ Timothy/meadow fescue } \\
\hline Pasture & 15 & & & & & \\
\hline Timothy & & 73 & 50 & 27 & 25 & 35 \\
\hline Meadow fescue & & 25 & 50 & 65 & 40 & 13 \\
\hline Silage & 19 & & & & & \\
\hline Timothy & & 79 & 35 & 46 & 28 & 41 \\
\hline Meadow fescue & & 18 & 53 & 50 & 31 & 16 \\
\hline Hay & 6 & & & & & \\
\hline Timothy & & 75 & 54 & 30 & 20 & 36 \\
\hline Meadow fescue & & 21 & 43 & 63 & 28 & 11 \\
\hline \multicolumn{7}{|c|}{ Timothy/red clover/meadow fescue } \\
\hline Pasture & 9 & & & & & \\
\hline Timothy & & 63 & 37 & 22 & 25 & 25 \\
\hline Red clover & & 3 & 26 & 4 & 1 & 14 \\
\hline Meadow fescue & & 32 & 37 & 67 & 50 & 16 \\
\hline Silage & 14 & & & & & \\
\hline Timothy & & 56 & 41 & 53 & 28 & 35 \\
\hline Red clover & & 9 & 29 & 27 & 6 & 19 \\
\hline Meadow fescue & & 31 & 28 & 17 & 36 & 20 \\
\hline Hay & 8 & & & & & \\
\hline Timothy & & 48 & 48 & 36 & 46 & 51 \\
\hline Red clover & & 15 & 26 & 10 & 1 & 15 \\
\hline Meadow fescue & & 35 & 23 & 41 & 15 & 18 \\
\hline
\end{tabular}


Vol. 4: 479-494.

Table 4. Average winter damage and proportion $(\%)$ of sown plant species in first harvest of first- to fifthyear swards in Rovaniemi in 1988-1992.

\begin{tabular}{|c|c|c|c|c|c|c|}
\hline \multirow{2}{*}{$\begin{array}{l}\text { Plant species and } \\
\text { harvesting system }\end{array}$} & \multirow{2}{*}{$\begin{array}{c}\text { Winter } \\
\text { damage } \\
\%\end{array}$} & \multicolumn{5}{|c|}{$\begin{array}{l}\text { Percent sown plants } \\
\text { Year of ley }\end{array}$} \\
\hline & & 1 & 2 & 3 & 4 & 5 \\
\hline \multicolumn{7}{|l|}{ Timothy } \\
\hline Pasture & 7 & 99 & 100 & 90 & 62 & 78 \\
\hline Silage & 19 & 95 & 100 & 78 & 64 & 49 \\
\hline Hay & 18 & 94 & 100 & 97 & 80 & 71 \\
\hline \multicolumn{7}{|l|}{ Meadow fescue } \\
\hline Pasture & 14 & 98 & 100 & 99 & 97 & 92 \\
\hline Silage & 16 & 92 & 100 & 90 & 96 & 73 \\
\hline Hay & 14 & 92 & 100 & 99 & 99 & 89 \\
\hline \multicolumn{7}{|l|}{ Meadow grass } \\
\hline Pasture & 11 & 99 & 100 & 98 & 99 & 94 \\
\hline Silage & 14 & 97 & 100 & 96 & 96 & 77 \\
\hline Hay & 14 & 82 & 100 & 92 & 96 & 66 \\
\hline \multicolumn{7}{|l|}{ Smooth brome grass } \\
\hline Pasture & 22 & 99 & 100 & 85 & 50 & 44 \\
\hline Silage & 30 & 99 & 100 & 89 & 79 & 60 \\
\hline Hay & 16 & 73 & 95 & 77 & 69 & 18 \\
\hline \multicolumn{7}{|l|}{ Timothy/red clover } \\
\hline Pasture & 5 & & & & & \\
\hline Timothy & & 98 & 30 & 77 & 68 & 58 \\
\hline Red clover & & 1 & 67 & 14 & 9 & 12 \\
\hline Silage & 22 & & & & & \\
\hline Timothy & & 97 & 16 & 66 & 56 & 55 \\
\hline Red clover & & 1 & 83 & 21 & 22 & 9 \\
\hline Hay & 23 & & & & & \\
\hline Timothy & & 98 & 14 & 49 & 45 & 55 \\
\hline Red clover & & 1 & 85 & 46 & 41 & 17 \\
\hline \multicolumn{7}{|l|}{ Timothy/meadow fescue } \\
\hline Pasture & 9 & & & & & \\
\hline Timothy & & 89 & 24 & 4 & 4 & 3 \\
\hline Meadow fescue & & 10 & 74 & 95 & 92 & 91 \\
\hline Silage & 16 & & & & & \\
\hline Timothy & & 93 & 7 & 5 & 1 & 3 \\
\hline Meadow fescue & & 6 & 92 & 94 & 98 & 68 \\
\hline Hay & 10 & & & & & \\
\hline Timothy & & 93 & 44 & 10 & 4 & 11 \\
\hline Meadow fescue & & 6 & 55 & 89 & 88 & 72 \\
\hline \multicolumn{7}{|c|}{ Timothy/red clover/meadow fescue } \\
\hline Pasture & 7 & & & & & \\
\hline Timothy & & 92 & 16 & 14 & 7 & 8 \\
\hline Red clover & & 1 & 52 & 11 & 16 & 3 \\
\hline Meadow fescue & & 6 & 31 & 74 & 76 & 79 \\
\hline Silage & 15 & & & & & \\
\hline Timothy & & 84 & 15 & 20 & 7 & 1 \\
\hline Red clover & & 2 & 75 & 18 & 15 & 5 \\
\hline Meadow fescue & & 13 & 9 & 61 & 74 & 71 \\
\hline Hay & 8 & & & & & \\
\hline Timothy & & 86 & 7 & 9 & 6 & 7 \\
\hline Red clover & & 3 & 84 & 29 & 28 & 5 \\
\hline Meadow fescue & & 9 & 8 & 61 & 63 & 85 \\
\hline
\end{tabular}




\section{Nissinen, O. \& Hakkola, H.: Effects of cultivation technique on grassland production}

In Ruukki, the highest yielding silage plants were smooth brome grass and timothy and in Rovaniemi, meadow fescue and meadow grass. The lowest yields were obtained from mixed swards of timothy and red clover. The total yield of young swards in Ruukki was 7240 to 9620 $\mathrm{kg} / \mathrm{ha}$, and in Rovaniemi 5030 to $7330 \mathrm{~kg} / \mathrm{ha}$. In old, fourth- to fifth-year swards, the lowest yields in Ruukki were obtained from meadow fescue, $1980 \mathrm{~kg} / \mathrm{ha}$, and in Rovaniemi from timothy, $2800 \mathrm{~kg} / \mathrm{ha}$. In Ruukki, production of grass for silage was highest with smooth brome grass, $3800 \mathrm{~kg} / \mathrm{ha}$, and in Rovaniemi, with meadow fescue, $5980 \mathrm{~kg} / \mathrm{ha}$ (Table 6).

The yields of hay swards, including aftermath, were generally higher than those of silage swards (Tables 5 and 6). In Ruukki, the highest yielding plant in hay swards was smooth brome grass, which had an average dry matter yield of $10640 \mathrm{~kg} / \mathrm{ha}$ in the first- to fifth-year swards. In Rovaniemi, meadow fescue had the highest average yield, $7170 \mathrm{~kg} / \mathrm{ha}$. In hay swards, timothy also thrived well at both trial sites. Aftermath accounted for one-third of the total dry matter yield an average.

It is clear from the trial that the economic use of sown grassland can not be prolonged with the plant species studied in any harvesting system. The yield of pasture and silage swards can, however, be significantly increased with the correct choice of plant species. In the trial, timothy and smooth brome grass were highly unsuitable for harvesting at the pasture stage, which explains well the poor yield production ability of timothy-dominated pasture swards in northern Finland. Meadow fescue and meadow grass also thrived well when there were several harvest cuts during the growing season. The yield formation of meadow grass was more rapid in Rovaniemi than in Ruukki, which supports the view of Andersson (1988) that meadow grass thrives relatively better the farther north it is grown.

In the trials dry matter yields were increased in plants harvested at a later stage of development, as found also by Raininko (1968). The smaller differences between total yields of sil-

Table 5. Average dry matter yields of different harvesting systems and plant species in Ruukki and Rovaniemi in 19881992

\begin{tabular}{|c|c|c|c|c|c|c|c|c|c|c|c|c|c|c|}
\hline & \multicolumn{3}{|c|}{ A. Harvesting system } & \multicolumn{6}{|c|}{ B. Plant species } & \multirow[b]{2}{*}{7} & \multicolumn{4}{|c|}{ Statistical significance } \\
\hline & $\mathrm{P}$ & $\mathrm{S}$ & $\mathrm{H}$ & 1 & 2 & 3 & 4 & 5 & 6 & & A & B & $\mathrm{A} \times \mathrm{B}$ & SE \\
\hline \multicolumn{15}{|l|}{ Ruukki } \\
\hline 1-3 year & $6700^{c}$ & $8520^{b}$ & $9190^{a}$ & $8620^{\mathrm{ab}}$ & $8530^{\mathrm{ab}}$ & $8240^{b}$ & $9000^{\mathrm{a}}$ & $7040^{c}$ & $8210^{b}$ & $7320^{c}$ & $* * *$ & *** & $* * *$ & 165 \\
\hline $4-5$ year & $3120^{b}$ & $3230^{b}$ & $3920^{a}$ & $2850^{\mathrm{cd}}$ & $2310^{d}$ & $3830^{b}$ & $5000^{a}$ & $2940^{\mathrm{cd}}$ & $3560^{c b}$ & $3450^{\mathrm{cb}}$ & $*$ & $* * *$ & $* * *$ & 165 \\
\hline $1-5$ year & $5310^{c}$ & $6400^{b}$ & $7080^{a}$ & $6320^{b}$ & $6100^{c b}$ & $6510^{b}$ & $7400^{a}$ & $5400^{d}$ & $6350^{b}$ & $5770^{\mathrm{cd}}$ & $* * *$ & *** & $* * *$ & 145 \\
\hline \multicolumn{15}{|c|}{ Rovaniemi } \\
\hline 1-3 year & $5050^{b}$ & $6500^{a}$ & $6610^{a}$ & $5230^{d}$ & $7080^{a}$ & $6490^{b}$ & $5310^{d}$ & $5490^{\mathrm{cd}}$ & $6910^{\mathrm{ab}}$ & $5860^{\circ}$ & $* *$ & *** & $* * *$ & 130 \\
\hline 4-5 year & $3290^{c}$ & $4500^{b}$ & $4940^{a}$ & $2980^{\circ}$ & $5840^{a}$ & $4520^{c}$ & $2970^{c}$ & $3420^{d}$ & $5380^{b}$ & $4580^{\circ}$ & $* * *$ & $* * *$ & $* * *$ & 145 \\
\hline $1-5$ year & $4340^{b}$ & $5700^{a}$ & $5940^{a}$ & $4330^{d}$ & $6580^{\circ}$ & $5700^{b}$ & $4370^{d}$ & $4660^{d}$ & $6300^{a}$ & $5350^{\circ}$ & $* *$ & $* * *$ & $* * *$ & 130 \\
\hline
\end{tabular}

$* \mathrm{P}<0.05 \quad * * \mathrm{P}<0.01 \quad * * * \mathrm{P}<0.001$

Means on same line with same superscript do not differ significantly $(\mathrm{P}<5 \%)$

$\begin{array}{lll}\mathrm{P}=\text { Pasture } & 1=\text { Timothy } & 5=\text { Timothy/red clover } \\ \mathrm{S}=\text { Silage } & 2 \text { = Meadow fescue } & 6=\text { Timothy/meadow fescue } \\ \mathrm{H}=\text { Hay } & 3=\text { Meadow grass } & 7=\text { Timothy/red clover } / \text { meadow fescue } \\ & 4=\text { Smooth brome grass } & \end{array}$


Vol. 4: 479-494.

age and hay swards were due to the high second yield of silage swards and the relatively poor aftermath of hay swards. In northern Finland, it is not possible to fully utilize the most rapid growth phase of grass for silage. The first yield has to be harvested at the beginning of the heading stage, before the crude protein content starts to decline, and the second so early that the swards have enough time to recover and harden before winter, as shown by Hakkola et al.(1987).

Table 6. Effect of harvesting system on dry matter yields in Ruukki and Rovaniemi in 1982-1992.

\begin{tabular}{|c|c|c|c|c|c|c|c|c|}
\hline \multicolumn{9}{|c|}{ Plant species } \\
\hline & 1 & 2 & 3 & 4 & 5 & 6 & 7 & $\mathrm{LSD}^{1}(\mathrm{P}<5 \%)$ \\
\hline & \multicolumn{7}{|c|}{ Dry matter yields, $\mathrm{kg}$ / ha } & \\
\hline $\begin{array}{l}\text { Ruukki } \\
\text { 1-3 year }\end{array}$ & & & & & & & & \\
\hline Pasture & 7140 & 7530 & 7680 & 5500 & 5860 & 7330 & 5900 & 830 \\
\hline Silage & 9090 & 9240 & 8290 & 9620 & 7240 & 8340 & 7790 & 1260 \\
\hline Hay & 9650 & 8830 & 8750 & 11870 & 8040 & 8950 & 8270 & 1580 \\
\hline LSD $(\mathrm{P}<5 \%)$ & 1330 & 850 & 1140 & 1280 & 930 & 880 & 1050 & \\
\hline 4-5 year & & & & & & & & \\
\hline Pasture & 2940 & 4200 & 4020 & 2400 & 2180 & 3170 & 2950 & 1410 \\
\hline Silage & 3110 & 1980 & 3420 & 3800 & 3320 & 3280 & 3680 & 1650 \\
\hline Hay & 2510 & 1200 & 4320 & 8790 & 3330 & 3520 & 3740 & 1340 \\
\hline LSD $(\mathrm{P}<5 \%)$ & 570 & 810 & 1380 & 1510 & 990 & 2010 & 990 & \\
\hline 1-5 year & & & & & & & & \\
\hline Pasture & 5460 & 6200 & 6220 & 4260 & 4380 & 5670 & 4720 & 790 \\
\hline Silage & 6700 & 6340 & 6350 & 7290 & 5670 & 6310 & 6140 & 960 \\
\hline Hay & 6790 & 5780 & 6980 & 10640 & 6150 & 6780 & 6450 & 1310 \\
\hline LSD $(\mathrm{P}<5 \%)$ & 790 & 520 & 900 & 1290 & 670 & 930 & 960 & \\
\hline $\begin{array}{l}\text { Rovaniemi } \\
1-3 \text { year }\end{array}$ & & & & & & & & \\
\hline Pasture & 4250 & 6300 & 6310 & 3340 & 4380 & 5960 & 4670 & 890 \\
\hline Silage & 5030 & 7330 & 7020 & 6650 & 5480 & 7080 & 6370 & 1230 \\
\hline Hay & 6340 & 7520 & 6070 & 5860 & 6200 & 7640 & 6500 & 1280 \\
\hline LSD $(\mathrm{P}<5 \%)$ & 330 & 1120 & 770 & 860 & 960 & 970 & 1170 & \\
\hline $4-5$ year & & & & & & & & \\
\hline Pasture & 2290 & 4900 & 4010 & 1570 & 2330 & 4660 & 3290 & 510 \\
\hline Silage & 2800 & 5980 & 4790 & 4010 & 3620 & 5580 & 4740 & 840 \\
\hline Hay & 3880 & 6650 & 4780 & 3330 & 4340 & 5890 & 5730 & 540 \\
\hline LSD $(\mathrm{P}<5 \%)$ & 420 & 730 & 570 & 500 & 560 & 630 & 410 & \\
\hline 1-5 year & & & & & & & & \\
\hline Pasture & 3460 & 5740 & 5390 & 2630 & 3560 & 5440 & 4120 & 580 \\
\hline Silage & 4140 & 6790 & 6130 & 5590 & 4950 & 6480 & 5720 & 960 \\
\hline Hay & 5350 & 7170 & 5550 & 4850 & 5450 & 6940 & 6190 & 760 \\
\hline LSD $(\mathrm{P}<5 \%)$ & 790 & 510 & 900 & 1290 & 670 & 930 & 960 & \\
\hline
\end{tabular}

$1=$ Timothy

2 = Meadow fescue

$5=$ Timothy/red clover

$6=$ Timothy/meadow fescue

$3=$ Meadow grass

7 = Timothy/red clover/meadow fescue

$4=$ Smooth brome grass

'LSD = Least significant difference 
Nissinen, $O . \&$ Hakkola, H.: Effects of cultivation technique on grassland production

Generally, dry matter yields of silage and hay swards were highest in the second crop year. As mentioned by Hagsand and Landström (1984), this is typical of grasses owing to inadequate growing density during the sowing year. With the exception of meadow grass, the dry matter yields of all plants harvested at the pasture stage in Rovaniemi declined after the first crop year, probably owing to the great stress of four cuts (Huokuna et al. 1985).

The increased cutting frequency reduced the yields of shortgrowing grasses, meadow fescue and meadow grass less than those of tall-growing grasses, timothy and smooth brome grass. After cutting, more leaf remains in stands of meadow fescue and meadow grass than in the stubble of timothy and smooth brome grass. As documented by Landström (1992), at the beginning of regrowth after the first cut, the growth rate was higher in meadow fescue than in timothy, reflecting the continuation of leaf growth in meadow fescue.

The timothy and meadow fescue mixture was no more productive than the pure stand of meadow fescue in Rovaniemi and or the pure stand of timothy in Ruukki. However, the production of a mixed stand of timothy and meadow fescue was very high at both trial sites and in all harvest systems, and it would therefore to be the best grass for general use in northern Finland. A mixed stand of grass species is better able to adapt to varying climatic conditions and different cultivation techniques than is a pure culture of a single grass. In the studies of Raininko (1968) and Hakkola (1988), the dry matter yields of a mixed stand of timothy and meadow fescue were higher than those of a pure culture of timothy or meadow fescue.

\section{Botanical composition of yield}

In general, as the sward aged, the proportion of sown plant in the yield decreased and that of weeds increased. The less suitable the plant species was for different harvest intensities, the faster the changes occurred (Tables 3 and 4). Win- ter damage as well as cutting frequency caused gaps where unsown grasses and dicotyledons could become established. However, in both Ruukki and Rovaniemi, the proportion of sown plants was fairly constant in all stands until the third crop year.

The clover content was higher in mixtures of timothy and red clover than in mixtures of timothy, red clover and meadow fescue. Swards harvested at the hay stage contained the most timothy, and swards harvested at the pasture stage the least. In a mixture, timothy thrived better with red clover than with meadow fescue. Smooth brome grass behaved similarly to timothy. In Rovaniemi, stands containing meadow fescue were still very dense even in the fifth-year swards. Likewise, the proportion of weeds in the yields of these stands was small. The proportion of meadow fescue in the mixed stands of plant species increased with cutting frequency. In the trial, meadow fescue supplanted timothy in the very first year. In Rovaniemi, a mixed sward of timothy and meadow fescue became a sward dominated by meadow fescue already in the second crop year. Meadow grass remained clear of weeds with all harvesting methods. In Ruukki, most of the sown plant species were still present in yields of mixed stands of timothy, red clover and meadow fescue in fifth-year swards. In Ruukki, the effect of the harvesting system was greatest on the amount of weeds in smooth brome grass. When harvested at the pasture stage, only $15 \%$ of smooth brome grass was present in the yield of the fifth-year sward, whereas in the plots harvested at the hay stage, smooth brome grass accounted for more than $90 \%$.

It was shown here, as elsewhere (Hagsand and Landström 1984, Grönneröd 1988, Jörgensen et al. 1994), that meadow fescue had a positive effect on sward density, both in a pure culture and in mixed stands containing it, even with the most intensive cutting regime, and also that it was well able to compete with weeds. In the mixtures, however, there was also a sharp increase in the proportion of meadow fescue at the expense of timothy and red clover. Initially, timothy made up more of the mixture than the 
Vol. 4: 479-494.

prescribed $50 \%$ mixture, mainly because of the higher number of seeds of timothy than of meadow fescue. However, in the trial, a mixed sward of timothy and meadow fescue turned into a meadow fescue -dominated sward in the second crop year, and most clearly in the swards cut at the pasture stage. The changes in botanical composition can be attributed both to different overwintering abilities and to interspecific competition between meadow fescue and timothy. Due to the strong competitiveness of meadow fescue, there was also less red clover in the mixture of timothy, meadow fescue and red clover than in the mixture of timothy and red clover. The decrease in clover content in swards was more rapid in Ruukki than in Rovaniemi, partly owing to the winter damage caused by frost and ice scorch.

\section{Quality of grassland yield}

Data on the quality of grassland yields are presented in Table 7.

Table 7. Average forage quality of yields harvested at pasture, silage and hay stage in Ruukki and Rovanie$\mathrm{mi}$ in 1988-1992.

\begin{tabular}{|c|c|c|c|c|c|}
\hline $\begin{array}{l}\text { Harvesting system } \\
\text { and plant species }\end{array}$ & $\begin{array}{l}\text { Ruukki } \\
\text { Crude } \\
\text { protein } \\
\%\end{array}$ & $\begin{array}{c}\text { Crude } \\
\text { fibre } \\
\%\end{array}$ & $\begin{array}{l}\text { Rovaniemi } \\
\text { Crude } \\
\text { protein } \\
\%\end{array}$ & $\begin{array}{c}\text { Crude } \\
\text { fibre } \\
\%\end{array}$ & $\begin{array}{r}\mathrm{OMD}^{1)} \\
\%\end{array}$ \\
\hline \multicolumn{6}{|l|}{ Pasture (first to fourth cut) } \\
\hline Timothy & 20.4 & 25.0 & 18.4 & 24.0 & 79.6 \\
\hline Meadow fescue & 21.0 & 26.7 & 16.7 & 24.5 & 82.2 \\
\hline Meadow grass & 21.7 & 27.5 & 17.4 & 27.8 & 79.3 \\
\hline Smooth brome grass & 22.7 & 25.9 & 19.0 & 26.3 & 80.3 \\
\hline Timothy/red clover & 18.6 & 23.8 & 19.4 & 22.2 & 80.1 \\
\hline Timothy/meadow fescue & 20.5 & 26.5 & 17.1 & 24.9 & 80.6 \\
\hline $\begin{array}{l}\text { Timothy/red clover/ } \\
\text { meadow fescue }\end{array}$ & 17.5 & 25.3 & 17.6 & 23.1 & 80.4 \\
\hline \multicolumn{6}{|l|}{ Silage (first to second cut) } \\
\hline Timothy & 15.6 & 31.1 & 14.7 & 26.5 & 74.1 \\
\hline Meadow fescue & 17.0 & 30.8 & 13.8 & 29.4 & 75.9 \\
\hline Meadow grass & 16.2 & 29.8 & 15.6 & 30.0 & 72.6 \\
\hline Smooth brome grass & 15.9 & 32.7 & 13.6 & 31.4 & 71.8 \\
\hline Timothy/red clover & 14.9 & 29.3 & 16.0 & 25.6 & 74.2 \\
\hline Timothy/meadow fescue & 15.5 & 31.1 & 13.6 & 29.1 & 75.5 \\
\hline \multicolumn{6}{|l|}{ Timothy/red clover/ } \\
\hline Meadow fescue & 14.2 & 29.8 & 14.9 & 27.6 & 76.2 \\
\hline \multicolumn{6}{|l|}{ Hay (first cut) } \\
\hline Timothy & 11.0 & 35.2 & 9.3 & 34.3 & 63.5 \\
\hline Meadow fescue & 11.4 & 34.2 & 8.7 & 36.2 & 63.9 \\
\hline Meadow grass & 11.8 & 33.9 & 10.0 & 32.7 & 70.8 \\
\hline Smooth brome grass & 10.9 & 36.6 & 8.5 & 31.9 & 66.9 \\
\hline Timothy/red clover & 9.7 & 34.7 & 11.9 & 34.3 & 62.8 \\
\hline Timothy/meadow fescue & 11.1 & 34.6 & 9.3 & 34.8 & 62.1 \\
\hline Timothy/red clover/ & & & & & \\
\hline meadow fescue & 9.3 & 35.2 & 11.3 & 34.5 & 62.4 \\
\hline
\end{tabular}

1) Organic matter digestibility, in vitro (pasture 1988-1992, silage 1991-1992, hay 1992). 
Nissinen, O. \& Hakkola, H.: Effects of cultivation technique on grassland production

The average crude protein content of forage crops harvested at the pasture stage was 16.7 to $22.7 \%$. In Ruukki, the highest average protein contents were in smooth brome grass and meadow grass and in Rovaniemi, in the timothy and red clover mixture, and in smooth brome grass. At the silage stage in Ruukki, the yields of meadow fescue contained the most protein, $17.0 \%$. In Rovaniemi, the protein content was the highest in the yields of a mixture of timothy and red clover, $16.0 \%$, and in meadow grass, $15.6 \%$. The protein content of hay swards was 8.5 to $11.9 \%$. In Ruukki, protein percentages were lowest in mixtures containing clover but in Rovaniemi, in hay swards containing clover protein contents were highest.

The differences in crude protein yields between plant species and harvesting systems were statistically significant (Tables 8 and 9). In Ruuk$\mathrm{ki}$, the total protein yield of all plants except smooth brome grass increased when the number of cuts was increased. In Rovaniemi, only meadow fescue and the timothy and meadow fescue mixture gave the highest protein yields in pasture swards. With all other plants, the best pro- tein yields were obtained from silage swards. In Ruukki, the highest amount of protein kilos in the first- to third-year swards was obtained from meadow grass harvested at the pasture stage, $1580 \mathrm{~kg} / \mathrm{ha}$, and in Rovaniemi, from a silage sward, $1070 \mathrm{~kg} / \mathrm{ha}$.

The variation in the average crude fibre content of pasture yields was 22.2 to $27.8 \%$. Meadow grass had the most fibre, and the timothy and red clover mixture the least. In most cases meadow fescue had more fibre than timothy. In Rovaniemi, the average fibre content was one percentage unit lower than in Ruukki but the variation between plant species was greater in Rovaniemi than in Ruukki. Meadow fescue had the highest organic matter digestibility, and meadow grass the lowest. The fibre contents of silage crops were 25.6 to $32.7 \%$. Smooth brome grass had the most fibre, and the timothy and red clover mixture the least. In Rovaniemi, the fibre content of timothy was lower than in meadow fescue at the silage stage, too. Meadow fescue and the mixtures containing it had the best average digestibility, and smooth brome grass the poorest. In Ruukki, the lowest crude fibre con-

Table 8. Average crude protein yields of different harvesting systems and plant species in Ruukki and Rovaniemi in 19881992.

\begin{tabular}{|c|c|c|c|c|c|c|c|c|c|c|c|c|c|c|}
\hline & \multicolumn{3}{|c|}{ A. Harvesting system } & \multicolumn{7}{|c|}{ B. Plant species } & \multicolumn{4}{|c|}{ Statistical significance } \\
\hline & $\mathrm{P}$ & $\mathrm{S}$ & $\mathrm{H}$ & 1 & 2 & 3 & 4 & 5 & 6 & 7 & A & B & $\mathrm{A} \times \mathrm{B}$ & SE \\
\hline \multicolumn{15}{|l|}{ Ruukki } \\
\hline 1-3 year & $1340^{\mathrm{a}}$ & $1280^{\mathrm{a}}$ & $1070^{b}$ & $1310^{\mathrm{ab}}$ & $1350^{\mathrm{a}}$ & $1330^{\mathrm{a}}$ & $1340^{\mathrm{a}}$ & $1020^{c}$ & $1240^{b}$ & $1020^{c}$ & $* * *$ & $* * *$ & $* * *$ & 25 \\
\hline 4-5 year & $540^{\mathrm{a}}$ & $570^{\mathrm{a}}$ & $520^{a}$ & $470^{\text {cd }}$ & $420^{d}$ & $690^{b}$ & $790^{\mathrm{a}}$ & $430^{d}$ & $560^{c}$ & $440^{d}$ & NS & $* * *$ & $* * *$ & 25 \\
\hline $1-5$ year & $1020^{2}$ & $990^{a}$ & $850^{b}$ & $970^{b}$ & $970^{b}$ & $1070^{a}$ & $1120^{\mathrm{a}}$ & $790^{\circ}$ & $970^{b}$ & $790^{\circ}$ & $* *$ & $* * *$ & $* * *$ & 20 \\
\hline \multicolumn{15}{|c|}{ Rovaniemi } \\
\hline 1-3 year & $830^{a}$ & $890^{2}$ & $700^{b}$ & $690^{b}$ & $840^{a}$ & $900^{2}$ & $670^{b}$ & $840^{\mathrm{a}}$ & $870^{a}$ & $850^{\mathrm{a}}$ & $* *$ & $* * *$ & $* * *$ & 15 \\
\hline 4-5 year & $600^{b}$ & $690^{\circ}$ & $580^{b}$ & $420^{\circ}$ & $840^{a}$ & $700^{c}$ & $420^{\circ}$ & $550^{d}$ & $770^{b}$ & $670^{c}$ & $* *$ & $* * *$ & $* * *$ & 20 \\
\hline $1-5$ year & $740^{a}$ & $810^{a}$ & $650^{b}$ & $580^{d}$ & $840^{\mathrm{a}}$ & $820^{\text {at }}$ & $710^{d}$ & $720^{\circ}$ & $830^{a}$ & $780^{b}$ & $* *$ & $* * *$ & $* * *$ & 15 \\
\hline
\end{tabular}

$* \mathrm{P}<0.05 * * \mathrm{P}<0.01 * * * \mathrm{P}<0.001$

Means on same line with same superscript do not differ significantly $(\mathrm{P}<5 \%)$

$\begin{array}{lll}\mathrm{P}=\text { Pasture } & 1=\text { Timothy } & 5=\text { Timothy/red clover } \\ \mathrm{S}=\text { Silage } & 2 \text { = Meadow fescue } & 6=\text { Timothy/meadow fescue } \\ \mathrm{H}=\text { Hay } & 3=\text { Meadow grass } & 7=\text { Timothy/red clover } / \text { meadow fescue } \\ & 4=\text { Smooth brome grass } & \end{array}$


Vol. 4: 479-494.

tent of hay yields was in meadow grass, $33.9 \%$, and in Rovaniemi, in smooth brome grass, $31.9 \%$.

In any harvest, there has to be a compromise between quantity and quality. The later the date of harvest, the greater is the yield, the lower is the crude protein content and the poorer is digestibility. Grass forage from pasture alone contains enough protein and energy for a milk yield of $20 \mathrm{~kg}$ per day. Animals fed with hay always need supplements to ensure quality. Silage is the basic roughage used by most farms in northern

Table 9. Effect of harvesting system on crude protein yields in Ruukki and Rovaniemi in 1982-1992.

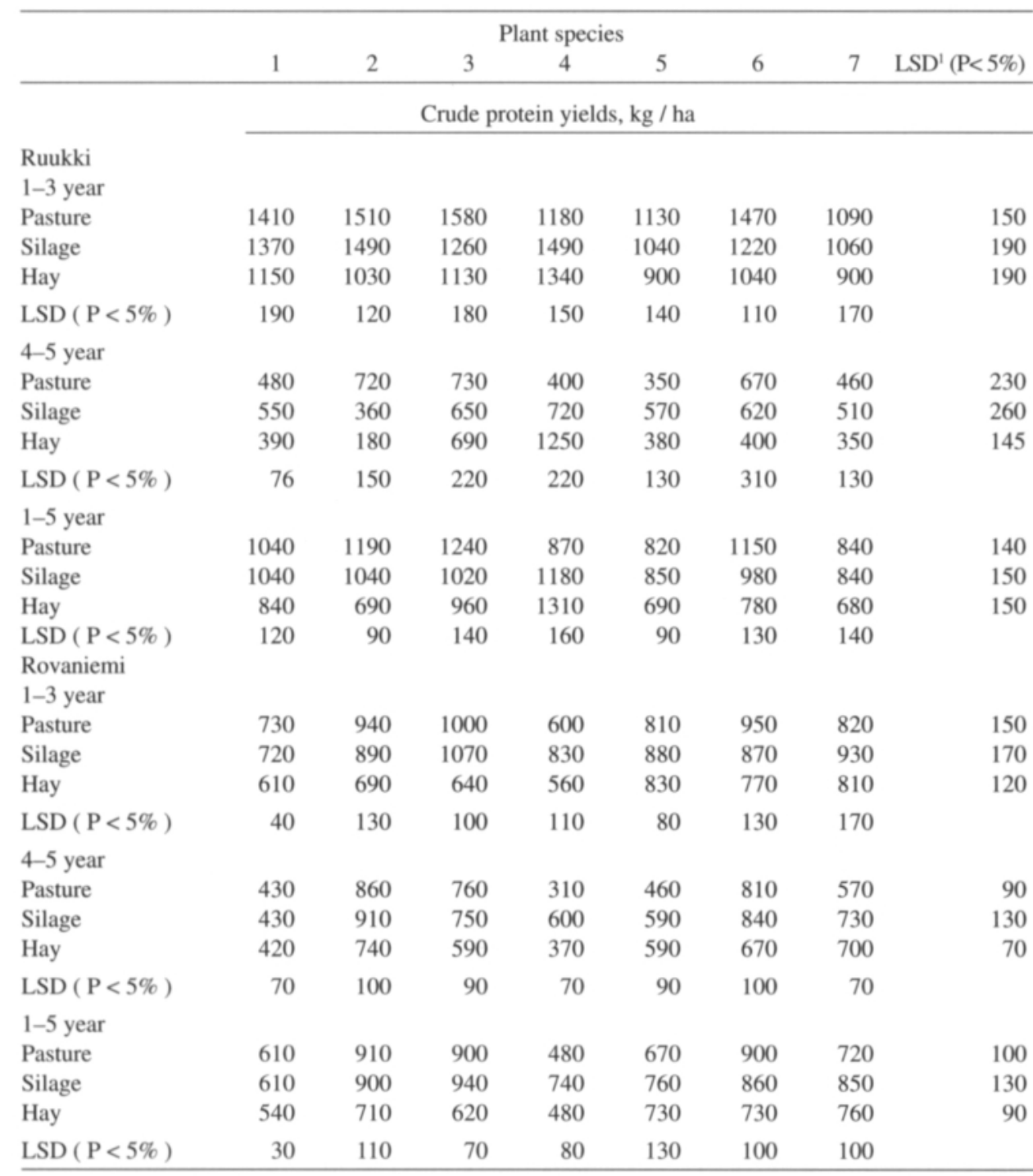

1 = Timothy

2 = Meadow fescue

$5=$ Timothy/red clover

$6=$ Timothy/meadow fescue

$3=$ Meadow grass

7 = Timothy/red clover/meadow fescue

$4=$ Smooth brome grass

'LSD $=$ Least significant difference 
Nissinen, O. \& Hakkola, H.: Effects of cultivation technique on grassland production

Finland. In making silage, the right timing of the harvest is very important for both the quantity and quality of the yield. The aim is to reach a $15-16 \%$ protein content in the dry matter of the grass for ensiling. In our trial, this objective was reached with all plant species and mixtures on average only in Rovaniemi, and even there only in the spring yield. Although the crude protein content decreases less rapidly in aftermath than in spring growth, the mean protein content of the second yield in Rovaniemi was only $12.7 \%$. The protein content of the yield also depends on nitrogen fertilization, yield quantity and the development stage of plants at the time of harvest. In the nitrogen fertilization trials of Andersson (1986), the amount of nitrogen had a greater effect on the protein content of the second harvest than on that of the spring harvest. According to Thorvaldsson (1988), the protein content of the spring harvest is higher than that of the second harvest at the same morphological development stage. The aftermath, has a longer growing time and the quantity of yield with respect to the development stage is higher than in the spring harvest, which, in addition to lower nitrogen fertilization, reduces the protein content.

As well as protein content, crude fiber and digestibility of the organic matter are important indicators of the feeding quality of forage. In grasses, the increase in fibrousness is most rapid at the time of straw growth (Salo et al. 1975). In the trial, when the plants were harvested at the same time, the difference in development stages may explain why meadow fescue had a higher fibre content $(29.4 \%)$ than timothy $(26.5 \%)$. Similar results were obtained in both the spring and aftermath harvests. In the aftermath, the higher fibre content of meadow fescue was probably due to the more rapid growth of meadow fescue than of timothy. In general, fibrousness increases less rapidly in the aftermath than in the spring harvest (Huokuna \& Hakkola 1984).

The increase in the fibrousness of plants at the time of straw formation is also connected to the decline in digestibility of the organic matter (Salo et al. 1975, Huokuna \& Hakkola 1984). Fibrousness does not necessarily determine digestibility. The amount of protein and its digestibility also play a role. Therefore, despite the higher fibre content, the digestibility of meadow fescue in Rovaniemi was better than that of timothy. On the other hand, the digestibility of fibrous meadow grass was poorer than that of timothy and meadow fescue despite the high protein content of meadow grass. In general, the crude fibre content does not seem to be a primary quality factor with any harvesting system. As Deinum et al. (1981) observed that, at the same morphological developmental stage, organic matter digestibility is higher in northern than in southern latitudes. The low temperature decreases the crude fibre content of dry matter. Another probable cause of better digestibility under northern growing conditions is the increased lignin content of timothy at higher growth temperatures (Ames et al. 1993).

\section{REFERENCES}

Ames. N., McElroy, A. R. \& Erfle, J. 1993. The effect of temperature on quality characteristics in timothy (Phleum pratense L.) genotypes. Canadian Journal of Plant Science 73: 1017-1026.

Andersson, S. 1986. Hur förbăttra fodrets proteinhalt? Rōbäcksdalen Meddelar 2. p. 4:1-4:9.

- 1988. Lång och kortvarig betesvall. Summary: Longand short-term grazing leys. Grovfoder. Sveriges lantbruksuniversitetet. Rapport 1. p. 5-19.
- 1989. Hög kvalitet pá vallfoder. När máste man skörda? Summary: High quality of ley forage. When should one then cut? Grovfoder. Sveriges lantbruksuniversitetet. Rapport 1. p. 5-14.

Deinum, B., Beyer, J. de, Nordfelt, P.H., Kornher, A., Ostgárd, O. \& Bogaert, G. van 1981. Quality of herbage at different latitudes. Netherlands Journal of Agricultural Science 29: 141-150.

Frankow-Lindberg, B. 1989. Kvăvegōdslingseffekter i 
Vol. 4: 479-494.

vall med olika andel rödklöver. Summary: The effect of nitrogen and clover proportion on yield of red clover-grass mixtures. Grovfoder. Sveriges lantbruksuniversitet. Rapport 1. p. 15-24.

Friedel, K. 1990. Die Schătzung des energetischen Futterwertes von Grobfutter mit Hilfe einer Cellulasemethode. Wissenschafliche Zeitschrift der Wilhelm-Pieck-Universităt, Rostock. Matematische-naturwissenschaftliche Reihe. 39: 78-86.

Grönneröd, B. 1972. Grass species, varieties, cutting intensity and fertilization. IAAS grass seminar. $11 \mathrm{p}$.

- 1988. The effect of cutting intensity on yield, quality and persistence of timothy. Proceedings of the 12th General Meeting of the European Grassland Federation, Dublin,Ireland. p. 392-396.

Gudleifsson, B. E. 1986. Máling av isdekketoleranse hos gras i laboratoriet. In: Lantbruksvăxternas övervintring. Rapport från NJF-seminar nr. 84, Jokioinen, Finland. p. 171-179.

Hagsand, E. \& Landström, S. 1984. Ensidig grovfoderodling i norra Sverige. Summary: One-sided forage production in northern Sweden. Röbăcksdalen Meddelar $4.74 \mathrm{p}$.

Hakkola, H. 1988. Heinănsiemenen kylvőmăåriă voidaan pienentăă. Koetoiminta ja kāytăntō $45: 5$

- 1991. Nurmen kevätlannoituksen ajankohta. Koetoiminta ja kăytăntő 48: 42.

-, Heikkilä, R., Rinne, K. \& Vuorinen, M. 1987. Odelman typpilannoitus, săngenkorkeus ja niittoaika. Maatalouden tutkimuskeskus. Tiedote 4/87. 39 p.

Hole, J.R. 1985. The nutritive value of silage made from Poa pratensis ssp. alpigena and Phleum pratense. 1.Ensiling studies carried out at Tjotta, Vågones, Holt and Flaten agricultural research stations. Meldinger fra Norges landbrukshögskole 16. 29 p.

Huokuna, E. \& Hakkola, H. 1984. Koiranheinăn ja timotein kasvu ja rehuarvon muutokset săilörehuasteella. Maatalouden tutkimuskeskus. Tiedote 8/84.54 p.

-, Järvi, A., Rinne, K. \& Talvitie, H. 1985. Nurmipalkokasvit puhtaana kasvustona ja heinäseoksena. Maatalouden tutkimuskeskus. Tiedote 22/85. p. 1-12.

Järvi, A. 1976. Heinălajien vertailua heină-odelmanurmella. Koetoimoiminta ja kăytăntō 33: 6 .

- 1982. Rehukattaran ja timotein niittoaika. Koetoiminta ja kăytăntō 39: 31 .

Jörgensen, M., Schjelderup, I. \& Junttila, O. 1994. Dry matter production and botanical composition of monocultures and mixtures of meadow fescue (Festuca pratensis Huds.) and timothy (Phleum pratense L.) in field experiments at three locations in northern Norway 198489. Norwegian Journal of Agricultural Sciences 8: 291299.

Landström, S. 1978. Grovfoderodling i norrlands inland. Delredovisning av försōksresultat 1973-77. Röbăcksdalen Meddelar 11. $44 \mathrm{p}$.

- 1989. Frekvensfördelning av tillvăxtindex fő vallproduktion i norra Sverige. Summary: Frequency distribution of growth index for grassland production in northern Sweden. Văxtodling $10.28 \mathrm{p}$.

- 1992. Growth analysis defining plant and weather interactions in timothy, meadow fescue and red clover mixture in northern Sweden. Crop Production Science 16. $33 \mathrm{p}$.

Mason, W. \& Lachance, J. 1983. Effects of initial harvest date on dry matter yields and protein in timothy, tall fescue, reed canarygrass and kentucky bluegrass. Canadian Journal of Plant Science 63: 675-685.

Nissinen, O. \& Hakkola, H. 1989. Timotei-nurminataseosnurmen viljelykelpoisuus Lapissa. Koetoiminta ja kāytăntō 46: 81.

- \& Salonen, A. 1972. Sclerotinia borealis-sienen merkitys nurmiheinien talvehtimisen heikentăjänä Helsingin yliopiston koetilalla Inarin Muddusniemessă vuosina 1950-65. I Säăolosuhteiden vaikutus Sclerotinia borealiksen esiintymiseen sekă heinălajien ja -lajikkeen vaikutus nurmen talvehtimiseen. Abstract: Effect of Sclerotinia borealis on the wintering of grasses at the Muddusniemi Experimental Farm of the University of Helsinki at Inari in 1950-65. I. The effect of weather conditions on the incidence of $S$. borealis and of the species and variety of the grass on the wintering of ley. Maataloustieteellinen Aikakauskirja 44: 98-114.

Olsen, E. 1978. Vekstrytme og kjemisk innhold gjennom vekstsesongen hos àtta grasarter. Forskning och forsök i lantbruket 29: 545-563.

Pulli, S. 1980. Growth factors and management technique used in relation to the developmental rhythm and yield formation pattern of a pure grass stand. Journal of the Scientific Agricultural Society of Finland 52: 281-330. - 1982. Nurmikasvit eri viljelyvyōhykkeillă. Koetoiminta ja kăytäntő 39: 18-19.

Raininko, K. 1968. The effects of nitrogen fertilization, irrigation and number of harvestings upon leys established with various seed mixtures. Acta Agralia Fennica 112. 137 p.

Salo, M.-L., Nykänen, A. \& Sormunen, R. 1975. Nurmikasvien koostumus, pepsiini-HCL-liukoisuus ja in vitro sulavuus eri kasvuasteilla. Abstract: Composition, Pepsin-HCL solubility and in vitro digestibility of forages at different growth stages. Journal of the Scientific Agricultural Society of Finland 47: 480-490.

Thorvaldsson, G. 1988. The morphological and phenological development of timothy as affected by weather, and its relation to nutritional value. Acta Agriculturae Scandinavica 38: 33-48.

Ảman, P. \& Lindgren, E. 1983. Chemical composition and in vitro degradability of individual chemical constituents of six swedish grasses harvested at different stages of maturity. Swedish Journal of Agricultural Research 13: 221-227.

Àrsvoll. K. 1977. Effect of hardening, plant age, and development in Phleum pratense and Festuca pratensis on resistance to snow mould fungi. Meldinger fra Norges Landbrukshögskole 56. 14 p. 
Nissinen, O. \& Hakkola, H.: Effects of cultivation technique on grassland production

\title{
SELOSTUS
}

\section{Kasvilajin ja korjuutavan vaikutus nurmen satotasoon Pohjois-Suomessa}

\author{
Oiva Nissinen ja Heikki Hakkola \\ Maatalouden tutkimuskeskus
}

Pohjois-Suomen viljellystä peltoalasta lähes $80 \%$ käytetään nurmirehun tuotantoon. Sadonkorjuun tehostuminen on kuitenkin nopeuttanut timotein katoamista nurmista, alentanut satotasoa ja lyhentänyt nurmien taloudellista käyttöikää.

Vuosina 1988-92 Maatalouden tutkimuskeskuksen Pohjois-Pohjanmaan tutkimusasemalla Ruukissa ja Lapin tutkimusasemalla Rovaniemellä suoritetun tutkimuksen tavoitteena oli selvittää kasvilajin ja niittotiheyden vaikutusta nurmen tuottokykyyn ja rehusadon laatuun. Kenttäkokeissa olivat mukana timotei, nurminata, niittynurmikka ja rehukattara sekä timotei-puna-apila-, timotei-nurminata- ja timotei-punaapila-nurminataseokset. Nurmet korjattiin laidun-, säilörehu- ja heinäasteella.

Niittotiheyden lisääminen heikensi kokonaissatoa kaikilla kasvilajeilla ja kasvilajiseoksilla. Eniten satotaso aleni ns. korsiheinillä, timoteilla ja rehukattaralla. Lehtiheinillä, niittynurmikalla ja nurminadalla korjuutavan vaikutus satoon oli verraten vähäinen. Näillä heinälajeilla sadonkorjuun jälkeen jää sänkeen aina myös lehtiä, joiden avulla odelman kasvu alkaa nopeasti heti niiton jälkeen. Laidunnurmien kokonaissadot olivat tutkimuksessa keskimäärin $74 \%$ heinäasteella korjattujen nurmien sadosta. Puna-apila ei vaikuttanut rehusadon määrään, mutta paransi sen ruokinnallista laatua. Sadonkorjuutavasta riippumatta nurmien kuiva-ainesadot alenivat nopeasti kolmannesta satovuodesta lähtien.

Tutkimuksessa timotei menestyi hyvin Ruukissa ja nurminata Rovaniemellä, mikä johtuu lähinnä erilaisista talvehtimisolosuhteista. Ruukissa talvituhojen aiheuttajina olivat etupäässä pakkanen ja jääpolte, kun taas Rovaniemellä tuhoja aiheuttivat talvituhosienet. Kuitenkin timotei-nurminataseosnurmi menestyi hyvin molemmilla koepaikoilla ja kaikilla sadonkorjuutavoilla. Kun käytännössä nurmea ei perusteta pelkästään yhtä korjuutapaa ajatellen, tutkimustulosten mukaan timotei-nurminataseos on hyvä yleisnurmi Pohjois-Suomeen.

Myöhäisellä kasvien kehitysasteella tapahtunut sadonkorjuu lisäsi kuiva-ainesatoa, mutta huononsi rehun laatua. Niittotiheyden lisääminen kohotti huomattavasti sadon valkuaispitoisuutta ja useimmissa tapauksissa lisäsi myös valkuaisen määrää pienentyneestä kuiva-ainesadosta huolimatta. Säilörehuasteella korjattaessa useimmilla kasvilajeilla päästiin tavoiteltuun $15-16 \%$ valkuaispitoisuuteen. Tällä valkuaistasolla tutkimuksen mukaan myös nurmisadon kuituisuus ja sulavuus täyttävät Pohjois-Suomessa hyvin ruokinnan asettamat vaatimukset. 